\title{
Learning From Fiction in Life and Philosophy
}

\section{Allen RT*}

Retired, UK

*Corresponding author: Richard Allen, 20 Ulverscroft Road, Loughborough, LE11 3PU, UK, Tel: 44 1509552743; Email: rt.allen@ntlworld.com

\section{Conceptual Paper}

Volume 4 Issue 1

Received Date: December 29, 2020

Published Date: January 29, 2021

DOI: $10.23880 /$ phij-16000161

\section{Abstract}

Like other 'problems' in philosophy, any pertaining to the possibilities of learning from philosophy arise from inappropriate presuppositions. In this case it is mostly that all knowledge must be explicit and supported by reasons and evidence. But most of our knowledge is tacit and he chain of evidence for evidence ad infinitum must be ended somewhere. Fictions, including literary ones, are widely used in used in life and the sciences to draw consequences practical and theoretical consequences. Literary fictions can go beyond purely factual knowledge to reveal how it felt to live at a given time and place; to engage the whole person, and not just the thinkers, in both the characters portrayed and also in the reader or listener; to bring important matters home to them, for the heart is usually more important than the head; to show the importance of models and authoritative persons; to illustrate and apply general principles; to reveal philosophical errors such that all action is sub specie bonum by creating characters explicitly intending to do evil for because it is hurtful, cruel or vengeful; to show that there is more than formal learning to what happens in schools, and how important it can be; and generally to give narratives of what life really is or can be, and not just the abstractions and statistics of social sciences.

Keyword: Examplars; Fictions; Learning; Philosophy; Tacit knowing

\section{Learning from Fiction as a Philosophical 'Problem'}

It may be appropriate to deal first with certain assumptions that could make learning from fiction problematic, and before examining some ways in which in philosophy and in life generally we can learn from works of fiction.

Therefore, this article approaches philosophy on the assumption that philosophical 'problems' arise from inappropriate assumptions and presuppositions, so that books and articles on 'the problem of -' beg the real questions from the outset. Consequently, what is definitely not needed is endless modifications to even commonly accepted solutions and formulations in order to cover the counterexamples offered against them or to cover other problems that they incur, as still happens after 60 or so years with the 'standard definition of knowledge' as 'true belief supported by evidence and reasons'. No, instead of these Ptolemaic epicycles upon epicycles, we should take the reverse and Copernican path of standing back and looking for the mistaken assumptions and presuppositions that have landed us in these quagmires, and then free ourselves from them. This does not entail that, with Wittgenstein and all other positivists, we must conclude that philosophy is itself a mistake from which we should free ourselves. On the contrary, it has the very important task of trying to bring to light what we already know or presuppose. At some level or other we form and employ principles and conceptions for acquiring knowledge and vetting claims to it, and for interpreting ourselves and other entities along with the world around us and our place and destiny in it, and thus for guiding our conduct in it, even though we may unaware of much of this, just as we learned the rules of our native tongue primarily without explicit knowledge of them. Hence we are all incipient philosophers, epistemologists, metaphysicians, 


\section{Philosophy International Journal}

moralists, and so on, just as we are to some degree or level inevitably historians, natural scientists, artists, politicians, economists, etc., because we inevitably form some concepts and categories about these activities and their contexts by engaging in them whether we realise this or not, even if our economics concerns only the income and expenditure of a household or our politics only rule, freedom, power and authority within it. Consequently, the problem of our ability to learn from fiction is really that of thinking that it is a 'problem'. Therefore, in turn, it is to be dissipated by reflection upon, examining and making explicit what and how we do and can learn from fiction, and by seeking out the philosophical presuppositions and assumptions that make it appear to be a problem. Indeed, such reflection will show that it has a central place in our cognitive endeavours.

The principal obstacle, I suggest, is that many philosophers, especially today, too easily incur a déformation profesionelle of assuming that all knowledge is explicit and can be put into propositions, and that those propositions, plus the logical relations among them, are what they should focus upon, rather than upon our experience and what we experience in the world around us. After all they spend much of their time reading other philosophers' writings and producing their own. And since knowledge is not knowledge if the propositions in which it is embodied are not true, then inevitability there is a serious question about learning from fictions. Also, it is easy for them to assume, from their daily work of examining arguments to see if they are logically sound and based on evidence, and of trying to produce ones that will pass those tests, that all thinking should be conducted in the same way, whereas in actual life and fiction it is not. So again, it can be hard to see what we could learn from the latter except what not to do.

If, on the contrary, we hold that explicit knowledge is but the visible tenth of the whole, while the tacit nine tenths controls it, and thus that knowing can never be wholly explicit, then we may well be in a position to expect that fiction may be a source of knowledge, and even of knowledge that perhaps cannot be conveyed, or wholly conveyed, in other ways. ${ }^{1}$ So, from this alternative approach, I offer some

1 On the tacit dimensions of knowing, thinking, perception and action, see Michael, Personal Knowledge, London, Routledge, 1958, especially Chap. 4. For shorter accounts and further developments and applications, see The Study of Man, Routledge, London, 1959, The Tacit Dimension, Routledge, London, 1966, and Knowing and Being (ed. M. Grene), Routledge, London, 1969.

The 'standard definition' of knowledge rise to many difficulties, but the fundamental one is the infinite series of infinite regresses that it generates because nothing can count evidence unless it is (a) true or real, and (b) supportive of that for which it is cited as evidence. So, either the evidence $B$ for A is itself an object of unevidenced true belief, and so knowledge always depends upon it, or, to be knowledge, according to the definition, it itself must be supported (a) by evidence $C$ for its truth and (b) D evidence for its support of B. But to be knowledge, $\mathrm{C}$ and $\mathrm{D}$ each require similar sorts of reflections upon fictions of various kinds and suggestions of what can be learned by their aid.

Fiction, the production of that which is not the case, is an exercise of our powers of imagination. It can be used for many purposes, the most obvious of which is entertainment, but there are more important functions of fictions to be noted, and, first, their practical and cognitive roles of thinking of what is not but might be.

\section{The use of Fictions for Drawing Theoretical and Practical Consequences}

At this point, I would like to mention the special Spanish sense of ilusión', which has been explained as 'the projective actualisation of desire with a plot", as defined by Julian Marías in his Breve tratado de la ilusión (1984), wherein he explained that only in Spanish and only since the Romantic period the old Latin word "ilusio", whose meaning was "delusion" or even "hallucination", started to have a positive meaning in relation with the futurising capacity of the person. The Spanish "ilusión" is, according to Marías, a method of personal knowledge and a method also to improve one's happiness'. ${ }^{2}$ Now 'the projective actualisation of desire with a plot' sounds exactly like what Collingwood called 'amusement art', that which is designed to raise and satisfy emotions there and then, especially, I would add, vicarious emotions sought in and aroused by most notably the thriller and romance, and the 'weepie' variety of the latter. ${ }^{3}$ But what it seems really to mean is our projection of possibilities of future opportunities, events and actions in order to work out what would be likely to happen and thus what we should decide to do now or in the near future. These projections are works of imagination, whether realistic and so possible and perhaps probable, or unrealistic and thus improbable and even impossible. The latter are illusions or delusions in the ordinary sense, yet both are 'fictions' because they are not realities. Our human life, in which we are not confined to the span of the immediate present, would be utterly impossible

knowledge, ad infinitum.

2 I am indebted to Dr Maria Nieves Gómez Álvarez and Prof. Harold Raley for this explanation.

3 The Principles of Art, Oxford, Clarendon Press, 1938, Chap. V. See also C.S. Lewis, An Experiment in Criticism (Cambridge, Cambridge University Press, 1961), in which he distinguishes a 'literary' interest in fiction which values the story and its details for their own sakes from a non-literary one which seeks vicarious wish-fulfilment, and, on vicarious emotions, R.T. Allen, 'Emotional Parasitism', Appraisal,Vol. 9. No. 2, October 2012, 34-40, which also illustrates emotional parasitism with examples from D.H. Lawrence's poems, The Rainbow, and Sons and Lovers, and 'Miss Read's' (Dora Jessie Saint, MBE) Village School and Village Diary. Indeed the last two books have a threefold pattern of emotional parasitism: the battleaxe of a lecturer at a Teachers' Training College lives off the emotions of her former pupil who is now a teacher and in turn lives of those of the school children. The 'child centred education' of those days offered opportunities for such parasitism. 


\section{Philosophy International Journal}

without the remembered past and the projected possibilities of the future. This is even more true of the modern age when so many possibilities are open to us, and lack of means no longer confines many to doing just what and where their forefathers have always done. In practical, daily life at least, knowledge cannot be confined, as in what is still the standard definition of it, to ascertained and evidenced fact which can only be of what has happened, but must include imagined possibilities of what may and may not happen and some estimates of the likelihood of each. As Bishop Butler so rightly said, 'To us, probability is the very guide of life.' ${ }^{4}$ The past, or what we know of it, can and should inform us as to what may happen, but decision and action can be based only on imagined projections which should be realistic but which nevertheless would still be realistic fictions and not ascertained realities.

Fiction can include impossibilities, as in stories of timetravelling, and, indeed, they are objectively fictitious in every context even if some people believe them to be possible and even real. Such fictions have a more serious use, for one way of proving that something is impossible is to suppose that it is true. This, in Euclidian geometry, is the reductio ad absurdum, whereby we prove that a theorem, thought to be true, is so because its denial proves to be self-contradictory. And so we adopt what we think to be a fiction, in order to show that it is false. Elsewhere we use it to draw unwelcome consequences from a proposal. In ethics, for example, it can be shown that, on Kant's principles, obedience to the Gospel command given to rich young man to sell all he has and give the proceeds to the poor, would be a breach of the moral law, because it cannot be 'a law of nature' because other people must buy in order for the rich young man to sell. So too would be self-sacrifice to try to save others, as by Capt. 'Titus' Oates on Scot's return from the South Pole, for the selfsacrifice of all would be pointless, yet such acts are almost universally held to be meritorious and in combat will gain a posthumous Victoria Cross or, otherwise, a posthumous George Cross. Again, Kant himself breached the same law by remaining single and childless, because if we all were to do that, there would be no one to provide for us when we are old and incapable, either directly or by providing the profits or tax receipts for pension providers to distribute. Ultimately, children, one's own or others', constitute all pension schemes. In economics, Ludwig von Mises demonstrated that a Marxist economy of 'production for immediate use' and not of commodities for sale, and hence without prices, would be impossible because there would be no data for what to produce and in what quantities, and often with what materials and by what processes. It would need an exchange economy with markets to set prices, which it could then use for its planning. Marxist economics, and others envisioning

4 The Analogy of Religion. (1736) 'Introduction' the abolition of money and markets, such as William Morris' News from Nowhere, were shown to be necessarily fictitious, and not just imaginary constructions, and therefore that some sort of market to enable an exchange economy is necessary for anything beyond one of wholly self-subsistent households or communes. ${ }^{5}$

Hence, we can learn, and clearly do so, from proposals and purely hypothetical suppositions which, at the start, can be fictions in the sense of not being considered as being true, and so, by working out what would follow from them, we can learn whether they are feasible or must remain dreams and never reality.

This leads us to literary fictions, of which some, such as Julian Huxley's Brave New World and George Orwell's 1984, are written in order to show that certain trends in modern life, if rigorously followed through, would produce very undesirable results, and thus to warn us against any attempt to make these fictitious societies real. Again, some science fiction can simply work out the consequences of a very different world, as in Clifford Simak's world in which there are seven sexes. ${ }^{6}$ Thus, by explicitly drawing logical consequences or by composing stories with imagined worlds, we can work out what else might well have to change in circumstances very different from our own, and also what we could and should, or not, do in them.

But philosophers preoccupied with formal logic and the conventional notion of knowledge as justified or evidenced true belief, have problems with counterfactual propositions, ones of the form, 'If A had happened when it didn't (or had not happened when it did), then B would have happened, which it didn't (or would not have happened when it did)', because of a seeming lack of evidence for them. ${ }^{7}$ As regards the natural world and physical artefacts, at least some can

5 Socialism: An Economic and Sociological Analysis, trans. J. Kahane, London, Jonathan Cape, new ed. 1951, Pt II Chap. I. See also, Michael Polanyi, The Logic of Liberty, Chicago, The University of Chicago Press, 1951, Chaps. 8-10 where he shows that central planning is impossible because of the extent of the span of control that would be necessary; that prices and profits are necessary to 'polycentric' economy; and that 'spontaneous orders' of mutual adjustments among the participants as opposed to 'corporate' ones designed beforehand and initiated and conducted by giving orders to the participants, are necessary, as markets, in the economy and in other forms in society generally.

6 As mentioned by Kingsley Amis in C.S. Lewis: Of This and Other Worlds, ed. W. Hooper, London, William Collins \& Sons, Fount Paperbacks, 1982, p. 190.

7 The alleged problem is complicated by the notion of 'truth-makers'. I have never been able to find out exactly what they are supposed to be: the actualities to which true propositions refer, which creates problems for states of affairs that are not actual but over and done with, yet to happen, or didn't happen; the evidence for the truth of such propositions; some combination of both; or something else altogether. 


\section{Philosophy International Journal}

be based on known regularities in the world, though, as with all statements about it, there are, or should be, tacit ceteris paribus clauses. In the human sphere predictions and especially counterfactuals are notoriously unreliable, yet still we often have to make them. The historical importance of certain battles, such as Salamis, Actium, Poitiers (732: Charles Martel's defeat of the Spanish Moors), Hastings, Waterloo, the Battle of Britain and D-Day consists in how different subsequent events would have been had they gone the other way, although just how different and in the longterm is very doubtful. Only very speculative guesses can be made, yet before such decisive events, some such guesses have to be made in deciding whether to take the risk and what to do to lessen the chances of failure. Thus books, plays and films about counterfactual projections from real history may be instructive in some ways, and perhaps uncomfortable ones, as about the sorts of people who would have been collaborators if Britain had been overrun by Germany in 1940 or had come to some accommodation with it, but they cannot be confidently accepted as what definitely would have happened.

\section{Fiction and Factual Knowledge}

It is also the case that we can acquire factual knowledge from historical fiction and also fiction set in places we may not know or know only vaguely. This, of course, depends upon their factual accuracy which in turn depends upon that of the author's own knowledge of the times, places, people, customs, ways of thinking and so on, although in some books factual accuracy does not matter, as in light romances set among the peerage and gentry in the Regency. Furthermore, especially in historical novels, there are often items which are historically wrong, not by mistake, but by design, as when a fictional character has dealings with an historical one, but most readers can discount them.

The important point here is that with these caveats historical fiction can provide what histories do not, a sense of what it was really like to live in such times and places because of the detail of the pictures drawn about them, and the imagined thinking, emotions, attitudes, actions and interactions of the characters, and the impacts upon them of the social structures, laws, customs, institutions, manners and events in and through which they conduct themselves. I have especially in mind the Gordianus series of novels of Steven Saylor and the Falco and now Alba ones of Lyndsey Davis, set in Rome respectively at the end of the Republic and in the time of Vespasian, Titus and Domitian, and the older novels of Mary Renault, set in ancient Greece, and of Alfred Duggan set in various times from the late Roman Empire to the Crusades. Similarly, serious fiction from the past can tell us much about what it was like to live in those periods, such as life among the gentry in the novels of Jane Austen, and in newly industrial Manchester in Mrs Gaskell's North and South, which showed the rest of the reading public at the time what life was really like there. Such works bring the past or present to life in a way that nothing else can. Such knowledge of what 'it is, or was, really like' cannot be adequately put into propositions as arguments, evidence and conclusions, as in the reports of official enquiries or sociological studies, which sometimes include particular examples in detail in order to give more of a sense of what conditions are like. But a novelist can do much more, as can a photograph, film, drawing or sketch, to bring it home to the reader or viewer by putting him imaginatively or by pictures in the situation itself instead of being merely told about it. Hence any philosophy which takes formal discourse and logic as its paradigms cannot assimilate such knowledge, and the inference to be drawn is not 'so much the worse for the latter', but the rejection of the paradigm as inappropriate for all knowledge.

\section{Fictions and the Whole Person and not Just Formalised Reasoning}

A philosopher's preoccupation with formalised arguments can also lead him to assume that such a mode of reasoning is the only possible or valid one. But actual life is not, nor cannot be, conducted in such a manner. Nor is this a mere concession to the irrationality of the uninstructed populace who are more moved by feeling than by proper arguments and evidence, but it is inherent in our condition. It is the heart that ultimately matters, not the head. For example, there are philosophers who, for all their professions about reason, evidence and arguments, will give only a grudging agreement at the time to evidence and argument that refutes some dearly held conviction of theirs, and who then will continue thinking and acting from that conviction as before. Fiction can show how it is events, and others' actions, attitudes and emotions and not abstract reasoning that can change the human heart. For example, in Silas Marner it is the arrival of little Eppie and the neighbourliness of the villagers and not any arguments and moral lectures that bring Silas back to a fuller human life from his self-imposed isolation. In Flannery O'Conor's Revelation Mrs Turpin, who regards herself as a 'respectable hard-working, church-going woman', but who, it is clear, judges others by appearances and in stereotypes, has been assaulted and called a warthog from Hell by an ugly girl whom she despises along with 'white-trash' and 'niggers'. That insult gets under her skin, and in the evening she has a vision of just those people, clean for the first time and in white robes, ascending into heaven, from which she realises that her self-satisfied respectability is not enough. ${ }^{8}$

8 Though I had previously read the story (in The Complete Stories of Flannery O'Connor, Farrar, Straus and Giroux, New York, 1971) I owe this example to a fascinating paper on 'Short Stories and the Tractability of Ethics' 


\section{Philosophy International Journal}

\section{Fiction and the Significance of Authoritative Persons, Models and Examples}

Indeed, it may well be the case that what matters most is not what is said but who says it. The tragedy of The Lord of the Flies is that Ralph, the oldest boy, and Piggy, fat and despised by many of the boys, both know what needs to be done, while Jack, the next oldest and his fellow choristers play at being hunters, and the 'little 'uns' run around unsupervised and so suffer from only eating fruit while some just disappear. But Piggy knows that it will be useless for him to talk to Jack and that Ralph must take charge. But, while Ralph agrees with what Piggy says about what should be done, Piggy's urgings have no effect upon him and he cannot bring himself to act, and so Piggy gets killed before the survivors are rescued.

Of course, an admired person can give mistaken advice. In Jane Austen's Persuasion Anne Elliot, aged 19, and daughter of a baronet conscious of his station in life, becomes engaged to Lt Frederick Wentworth, RN, who is handsome, clever, confident and ambitious, but comes from an undistinguished family and has no money. Her father and elder sister oppose the match, and her older friend Lady Russell, who takes the place of her late mother, urges her to break the engagement because it would be imprudent for one so young. She takes Lady Russell's advice, though she loves Wentworth and he loves her. Seven years later, when the Napoleonic wars have ended, Wentworth, now a Captain and with prize money, returns. Eventually he realises that she still loves him and he proposes a second time and is accepted. But Anne has had to endure being taken from granted and imposed upon for those seven years with little prospect of real happiness, because it was Lady Russell's advice that mattered to her more than her own feelings.

In contrast, in Emma it is Mr Knightly, the most respected and prominent man in the village and who sometimes fills a space left by the death of Emma's mother and the neglect on the part of her valetudinarian father, who so sharply rebukes Emma for joining in the ridiculing of Miss Bates, whose financial and social situation has declined much from that in which she was brought up, that it stings Emma and makes her feel heartily ashamed of herself for so doing at the trip to Box Hill.

\footnotetext{
given by Dr Eileen John at a conference on 'Philosophy of and in the Short Story', at the University of Warwick, in June 2013. Her general theme was the ability of the short story to focus upon a particular moment in life, and how this is manifested in stories which are not nihilist but question some of the requirements laid down by many philosophers for rational approval of answers to 'How should we live?', and which appreciate, with a sense of ethical value, loss, tragedy, obsession and catastrophe. Other examples were taken from Borges, Melville and Kafka.
}

This brings us to the theme of examplars and models, which contemporary moral philosophy appears to ignore because of its focus upon explicit knowledge and its application, as does educational theory which confines itself to explicit teaching or to assisting learning when it shies away from definite teaching and commends offering suggestions instead. ${ }^{9}$ An example or model (not a mere 'rolemodel') has two functions: inspiration and tacit guidance. As inspiration a model shows what can be done, and displays admirable traits of character and temperament, such as courage, endurance and loyalty in doing it. As a tacit guide, such a person's conduct tacitly offers guides for conduct which cannot be codified, except in very general injunctions, but which followers, as apprentices to a master whose authority they accept, tacitly pick up from it. ${ }^{10}$ As regards general attitudes and conduct in life, rather than specific skills, the actual presence of an example or model may not be necessary, as is shown by ideals such as that of 'the gentleman' which are given substance by particular comments, as on the gentlemanly or ungentlemanly character of what someone has done. Also, models can be taken from history or legend, and even manifest fiction. Indeed, it may be the case that life imitates art as much as art imitates life. Perhaps it would not have really mattered in ancient Greece if the historicity of the Homeric heroes had been questioned, for even as fictions they could have remained models for young men. Byron himself was a model for Romantic youths who only read or read about him, and Goethe's Werther has been said to inspire suicides among the same. Models in life and fiction, as with advice from authoritative figures, can be for good or bad.

Frederick Farrar said of his Eric or Little by Little (1858), The story of 'Eric' was written with but one single objectthe vivid inculcation of inward purity and moral purpose, by the history of a boy who, in spite of the inherent nobility of his disposition, falls into all folly and wickedness, until he

9 This disposition is reinforced today by liberal scepticism about values and consequent fear of 'indoctrination', so that, as I have seen, it becomes enough to supply 'skills and information' to pupils and others generally, and for them to choose what to do with them. But skills do not tell us if, when and where to use them-as Plato said, a doctor's training enables him to kill as well as cure; nor does information tell us what, if anything, we should make of it.

10 Max Scheler deals with the them in 'Vorbilder und Führer', Gesammelte Werke, Vol. X, Berne, Franke Verlag, 1954-85, but only as inspiring their followers and not as models of conduct, and also in Formalism in Ethics and the Non-Material Ethics of Value, trans. M.S. Frings and R.L. Funk, Evanston IL, Northwestern University Press, 1973, pp. 299ff, 572ff.

On tacit learning from an example see Michael Polanyi, Personal Knowledge, Chap. 4, especially p. 54: 'By watching the master and emulating his efforts in the presence of his example, the apprentice unconsciously picks up the rules of the art, including those which are not explicitly known to the master himself'. On virtues as uncodifiable, see J. McDowell, 'Virtue and reason', and R. Hursthouse, 'Normative virtue ethics', both in ed. S. Darwell, Virtue Ethics, Oxford, Blackwell, 2003, respectively pp. 121-43 and pp. 184-202. 


\section{Philosophy International Journal}

has learnt to seek help from above. I am deeply thankful to know-from testimony public and private, anonymous and acknowledged - that this object has, by God's blessing, been fulfilled. ${ }^{11}$

That is, it was written as an example of what not to do until Eric finally seeks help to lift himself out of selfdegradation. But romans à clef like Eric are likely to be heavyhanded, obvious, contrived, unrealistic and unconvincing. Action and character need to develop organically out of each other, as in Shakespeare's great tragedies and Jane Austen's novels.

As well as concrete examples in extended and detailed stories, fictions can illustrate general principles in shorter forms, such as fable and parable, which are likely to hold the attention of the audience and bring home their significance in ways that bare statement of them cannot. A classic example is Nathan's parable to David of the rich man and the poor man's only possession, a ewe lamb, which the rich man took to serve to a visitor: a parable which he told after David had become enamoured of Uriah's wife, Bathsheba; had arranged for Uriah to be killed; and then had married Bathsheba. David, angry at the rich man, says he should surely die and pay four-fold for the lamb, because he acted wickedly and cruelly. Nathan then says, 'Thou art the man', and David confesses his sins. ${ }^{12}$

\section{Fiction and the Denial of Wilful Evil}

Literary fictions have also disproved the rationalism, in theology as well as philosophy, which explains away pure malice and spite with the Aristotelian and Scholastic doctrine that the will is determined by the good and thus all action is sub specie bonum, so that evil and wickedness stem from mistaken beliefs about what is really good, and, in turn, the key to moral reform lies in correcting those beliefs, the head and not the heart. Another story by Flannery O'Connor, A Good Man is Hard to Find, shows us three men who have escaped from prison calmly shooting the members of a family whose car has crashed. Eileen John says that their leader, 'The Misfit', has his reasons for this, a balancing of crime and punishment, and not just pleasure in killing. ${ }^{13}$ But they strike me as his rationalisations of unmotivated murder. For even when the grandmother says she recognises him as the escaped prisoner, and The Misfit says he must now kill her, his companions have already killed the rest of the family. And for what other reason did they, in the middle of their flight, stop by the crashed car? Obviously, not to help its occupants.

11 Quoted from https://en.wikipedia.org/wiki/Eric,_or,_Little_by_Little.

12 2 Sam. 11:2-12:13.

13 n. 7.
Shakespeare gives us atleast three 'Machiavels' in Richard III, Iago and Edmund, who deliberately act wickedly. The first turns villain, so he says, because of his misshapen form which gives him no chance of being a lover. Iago rationalises his hatred of Othello because Othello has chosen Cassio to be his lieutenant and not Iago. Finally, Edmund, because he is Gloster's illegitimate son but reckons himself as good as Edgar, the legitimate one and heir, seeks to seize Edgar's lands. He next conspires with both Goneril and Regan against their husbands, yet does try to redeem himself at the end by cancelling, but in vain, his order for Cordelia and Lear to be killed. All these act from sheer spite and malice for which they give themselves specious justifications. So too does Milton's Satan, who refuses to accept his place in heaven and all the happiness that goes with, and so motivated by pride, envy and revenge wages hopeless war against God and seeks only to spoil and destroy his creation, especially mankind, and ultimately himself with it, as shown figuratively by his everdecreasing size and literally by his increasingly incoherent and absurd reasoning, as when he pretends to infer that he was not created because he cannot remember the event. ${ }^{14}$

\section{Fictions as Providing What Academic Studies Neglect}

Finally, because academic attention can easily be restricted to abstract reasoning and stated evidence, fiction can deal with matters that theory ignores. One field in which this has happened is the academic study of education which tends to focus exclusively upon on schools, the formal curriculum of what is explicitly taught, teachersin their strictly professional capacities, and pupils in their corresponding role of those being taught. Homes and parents hardly appear, and when they do it is mostly as obstacles to schooling. Such deficiencies would require much more study but here only two or three such topics can be briefly mentioned. They are example, ethos and atmosphere, which are connected as being mostly tacit ways in which the young learn, and which particularly affect emotions and traits of character. The intellectual and practical importance of example has already been mentioned. Beyond that adults, whether they mean to or not, or like it or not, inevitably by their own demeanour, conduct, and expressions affect the young. Thus teachers can be dry, dull and uninspiring, or enthusiastic and inspiring, sympathetic or unsympathetic, models of good manners or bad. For example, part of the tragedy of Rattigan's The Browning Version is that Crocker-Harris, who teaches Classics at a public school and is about to retire, is academically gifted but strict, dull and uninspiring, and so is despised by the boys. He is set in contrast with another master whom the boys like. A poignant moment is when one boy, feeling

14 Paradise Lost, of course, is meant as cosmic and then terrestrial history, but with imagined and therefore fictional details. 


\section{Philosophy International Journal}

sorry for him, gives him a copy of Browning's translation of Aeschylus' Agamemnon, as a leaving present, but for which Crocker-Harris immediately expresses his contempt, which upsets the would-be well-wisher. It is in such terms that we remember much of school life, long after we have forgotten the details of what we learned, though a tacit framework may remain which enables us to place at least some of them when we come across them again and recall something about them, and also how it affects them.

As well as the effects of individuals, there is that of the whole: its prevailing 'atmosphere' of its emotions and attitudes, whether it generally goes about its work quietly and efficiently or noisily and disorderly, is friendly and welcoming or cold and hostile; and its ethos, the set of values and standards that it actually upholds and strives to achieve and maintain, including the non-ethos of appearing not to uphold and strive for any. ${ }^{15}$ It is by these that visitors are immediately impressed, disappointed or downright repulsed by an institution, meeting, social function or informal group. In respect of education, this is the informal aspect of education, often more important than the former, especially when the wrong sorts of examples, atmosphere and ethos are dominant, and teachers face almost insurmountable difficulties. Again, it is usually works of fiction, in novels, plays and films, that we see these aspects of schools, but as far as I know, only in part in serious fiction, because the main narrative is mostly set outside school, as with Lawrence's sketch of Ursula's dreams and realties as a teacher in an elementary school in The Rainbow, and the school in Winifred Holtby's South Riding, as the place and reason why the new headmistress and gentleman-farmer with his daughter are brought together. But in the earliest of 'Miss Read's' gentle comedies, Village Diary and Village School which have their more series moments, the village school is their focus,

15 On ethos, see Max Scheler, Formalism in Ethics, pp. 299ff, $572 \mathrm{ff}$. because the narrator is the fictional headmistress.

\section{Conclusion}

Learning from fiction presents philosophical problems only if it is approached with inappropriate assumptions and presupposition of a predominately rationalist and intellectualist character, not only on the part of philosophy itself but by other academic studies. Once it is acknowledged, as we should, that genuine knowledge is not confined to such forms, then the contributions that fiction can make can be properly appreciated. It is ironic that some contemporary philosophers who appear to share these inappropriate assumptions and presuppositions themselves indulge in fictions to support their arguments, as in imagining what brains in vats could be made to experience, such as having memories transplanted to them. ${ }^{16}$ Again, they themselves may well employ the fictions of counterfactuals to explore a topic or prove a thesis.

In respect of such imaginative constructions and of their use as examples, published fiction, as in this article itself, has the advantage that, as C.S. Lewis somewhere said, it is publicly available and may be generally known, unlike a true story of the Smiths down the author's road. And all good fiction, from the shortest parable to the longest novel, drama or film, has the advantage of giving, in at least some living and vivid detail, concrete characters, actions and events which can hold the audience's or readership's attention, be convincing in themselves, reflect and enlarge our own experiences of life, and strike home in a way that argument and cited evidence often cannot.

16 The error in this example is that whatever it is that is transplanted by that very fact would not be the brain's own memories but merely pictures and sounds that spontaneously appear to it, that is, if a mere brain, without the person or animal whose brain it is, could experience anything.

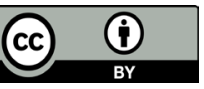

